\title{
Lexical-Semantic Aspect of the Concept "Actions, Behavior" (On the Material of the Tatar and English Phraseological Units with the Component-Zoonym)
}

\author{
Alfiya A. Gimadeeva ${ }^{1} \&$ Rasilya R. Nurmieva ${ }^{1}$ \\ ${ }^{1}$ Kazan (Volga Region) Federal University, Kazan, Russia \\ Correspondence: Gimadeeva A. Gimadeeva, Kazan (Volga Region) Federal University, 420008, Kazan, \\ Kremlyovskaya Street 18, Russia. E-mail: Alfiya-Gimadeeva@mail.ru
}

Received: June 2, 2015 Accepted: June 15, 2015 Online Published: June 29, 2015

doi:10.5539/jsd.v8n5p212

URL: http://dx.doi.org/10.5539/jsd.v8n5p212

\begin{abstract}
The urgency of the problem under investigation is stipulated by the fact that the study of concepts through their linguistic explicates is currently one of the problems of the modern cognitive linguistics, which in turn, helps to reveal the very structure of the concept. A comparison of the equivalent concepts in the Tatar and English language pictures of the world allows disclosing their cultural identity. The purpose of the article is to determine the lexical-semantic features of the concept "actions, behavior" as well as identify the universal and national characteristics in representation of the analyzed concept through phraseological means of the Tatar and English languages. The science-based approach will dominate in the process of this problem investigation. We used the general scientific methods of research in the study, such as descriptive-analytical and comparative. The authors also applied the methods of component, contextual and statistical analysis. The method of idiomatic modeling is partially used in the article as well. The main results of the article. The names of the animals within the phraseological units are mainly used in figurative sense. As a rule, certain characteristics and features of people are transferred through a definite image of an animal. We have revealed universal and national features in the analyzed concepts and their representations by phraseological means of the Tatar and English languages. About 25 animal names have been involved in the Tatar and English phraseological units. The materials of this article can be useful for students, master program undergraduates, post-graduate students while learning Tatar and English. Information on "language pictures of the world" of various linguocultural communities can be applied in the methods and practice of teaching above-mentioned languages.
\end{abstract}

Keywords: phraseological unit, concept, component-zoonym, Tatar, English

\section{Introduction}

Phraseological units with a component-zoonym are of particular interest for the linguistic-cultural and cognitive studies due to their versatility, frequency of use and phraseological units formation processes productivity involving zoonyms in modern languages, as well as a variety of cultural connotations they are able to "code". The study of the afore-named phraseological units also fosters identification of the basic mechanisms and features of the human internal and external world understanding, human behavior and relationship in the society. "Language is very closely linked with culture: it grows into it, develops in it and expresses it," writes V. A. Maslova (Maslova, 2004).

A man is able to understand the world and himself through language, which secures socio-historical experience, both universal and national.

Interest towards the language picture of the world has been detected in the works by W. Humboldt, who wrote that "different languages are the organs of the original thinking and perception for a nation" (Humboldt, 1984).

It should be noted that phraseological units plays special role in creation of a language picture of the world. "The phraseological units meaning nature is closely associated with the background knowledge of the native speaker, his practical experience of the individual, cultural and historical traditions of the nation, speaking this language" (Galimova, 2004). Phraseology "primarily explores communicative processes and links of language expressions used in them with synchronously existing mentality of the nation" (Telija, 1996). 
World reflected through the lens of the secondary sensations mechanism imprinted in metaphors, similes, symbols - is the main factor determining the versatility and peculiarity of any particular national language picture of the world. Herewith, it is important to distinguish between the human factor and the national identity in different language pictures of the world. Human activity is both universal and specific. This interaction results in creation of the world language pictures having both typologically common and individual characteristics.

The phraseological units semantics reflect a long process of cultural development of the nation; they record, and transmit cultural attitudes and stereotypes from generation to generation. "The inexhaustible depths of phraseology bear the great knowledge regarding the everyday life of different nations, their traditions and customs, behavior etiquette, moral and ethical foundations" (Zykova, 2003).

\section{Methodological Framework}

The following tasks have been performed in the process of study: review the process of phraseological units formation within the scope of cognitive and linguistic- cultural aspects; identify the features of the language verbalization in the studied concepts and make their systematic description in the Tatar and English languages; reveal the manifestation of universal and national characteristics in the analyzed concept and its representations through phraseological means of the Tatar and English languages.

We used such scientific methods of research as descriptive-analytical and comparative. The authors also used the methods of component, contextual and statistical analysis in the process of study.

The method of phraseological modeling is partially used in the article as well. The method of culture study analysis has been applied for study of the national consciousness content.

The card catalogue data compiled by the authors using the method of continuous sampling from Tatar and English dictionaries served the empirical basis of the research.

\section{Results}

First of all, it should be noted that the representation of the concept in the language is attributed to the word, thus the word getting the status of the concept name - a language sign, most fully and adequately transmitting the contents of the concept. Some of the concepts include lexical units, their meaning constituting the content of the national language consciousness and forming a native speakers" "naive picture of the world". We assumed the fact that the word itself as well as its verbal definition fixes the results of the cognitive efforts of the human mind. Key lexical units are culturally marked components contributing to the revealing of the national outlook and way of thinking.

In the Tatar language the analyzed concept is expressed through lexical units кыланыш (kylanysh) and тәртип (tartip). According to the dictionary definitions, the кыланыш (kylanysh) lexical unit has the following meanings: "1. берәр эшләнгән эш, башкарылган эш-хәрәкәт - berar eshlangan esh, berar bashkarylgan esh-harakat, ("act, action"); 2. кемнең дә булса үз-үзен тотышы - kemnen da bulsa uz-uzen totyshy" ("behavior") (Tatar telenen anlatmaly suzlege, 2005). Тәртип (tartip) means: "1. билгеле бер урында әйберләр, жиһазлар һ.б.ш. нәрсәләр урнаштырылышында максатчан эзлеклелек, уңайлык, жыйнаклык - bilgele ber urynda aiberlar, zhihazlar h.b.sh narsalar urnashtyrylyshynda maksatchan ezlelek, unailyk, zhyinaklyk ("expedient sequence, convenience, subjects placement accuracy, furniture in a certain place"); 2. кешеләр тупламында, күп кешеләр жәлеп ителгән эшчәнлек өлкәсендә h.б. эзлекле бүленеш һәм кагыйдәләр, боерыклар h.б.ш. үтәлешендә тайпылышсызлык, максатчанлык, көйләнгәнлек - keshelar tuplamynda, кup keshelar zhalep itelgan eshchanlek olkasenda h.b. ezlekle бүленеш ham kagyidalar, boeryklar h.b.sh. utaleshenda taipylyshsyzlyk, maksatchanlyk, koilanganlek ("consecutive division, firmness, purposefullness, co-ordination for implementation of rules, orders in a group of people and in attraction sphere of a large number of people"); 3 . ижтимагый корылыш системасы - izhtimagij korylysh sistemasy ("system of social facility"); 4. . кагыйдәләргә һәм боерыкларга буйсынучанлык, шуларны ригая итү күренеше һәм дәрәжәсе, дисциплина - kagyidelerge həm boeryklarga buysyinuchanlyk, shularny rigaya itu kureneshe həm derezhese, disciplina ("obedience rules and orders, their respect, discipline"); 5. беришле нәрсәләрне санап киткәндә билгеле бер гомуми нигез - berishle nerselerne sanap kitkende bilgele ber gomumi nigez ("the common ground at count of similar, identical subjects"); 6. билгеле бер катлаулы эшнең, шөгыльнең башкарылышында кабул ителгән аерым баскычлар, операцияләр эзлеклелеге - bilgele ber katlauly to the eshnen, shogylenen bashkarylyshynda kabul itelgen ayerym baskychlar, operatsijalar ezleklelege" ("sequence of steps and operations when performing any difficult business, actions") (Tatar telenen anlatmaly suzlege, 2005). The circumnuclear zone of the analyzed concept is revealed via lexical units disciplina / discipline; кыланмыш - kylanmysh / grimacing, apery; кыйланмыш - kyilanmysh / grimacing, apery; кыланчыклык - kylanchylyk/apery. 
In English the analyzed concept is expressed through lexical units of action and behavior. Action means: "1. the process of doing something, especially in order to achieve a particular thing; 2 . something that someone does; 3 . fighting during a war; 4. legal or formal process to decide whether someone has done something wrong; 5 . exciting things that are happening; 6 . the events in a story, film, play etc; 7. way something moves or works; 8 . the effect that a substance, especially a chemical, has on something" (Longman Dictionary of Contemporary English, 2009). According to the dictionary definitions, behavior expresses the following meanings: "1. way somebody behaves, especially towards other people; one's attitude and manners; 2 . way somebody/something acts or functions in particular situations" (Oxford Advanced Learners' Dictionary, 1995). The circumnuclear zone of the analyzed concept is revealed via lexical units conduct, deed, act, demeanor, deportment.

The variability of the images designating actions and behavior is peculiar to the analyzed languages.

Interlingual equivalents have been found in both languages: - дүрт аякль ат та абына - durt ayakly at ta abyna - the horse has four legs and yet he (it) of stumbles; Buridan ishage - Buridan's ass.

It should be noted the component analysis given below shows that the phraseological units of the identical meaning are formed on the different image bases which is usually a specific national feature of world perception.

- аюны үтермәс борын аның тиресен бүлү / сату - куянны үтермәс борын тиресен сатмыйлар тумаган тайны иярләү / дагалау - атмаган куян, асмаган казан - алмаган тавык, салмаган йомырка - tо sell the bear's skin before one has caught the bear-never fry fish till it is caught - to eat the calf in the cow's belly;

дөя дә бүләк, төймә дә бүләк - to look a gift horse in the mouth;

- тавыклар көләр - enough to make a horse / cat laugh;

- эт каргышы бүрега төшми - curses like chickens, come home to roost;

- кетәк ачкычын төлке муенына асу - кәбестә бакчасына кәжсә жстбәрү - to set a fox to keep the geese they put the wolf in charge of the sheep;

- дунзгыздан бер кыл - even a mangy sheep is good for a little wool.

It is possible to notice also the existence of images` coincidence in both languages:

- бүре баласын бүреккә салсаң да, урманга карый - no matter how long you feed a wolf, he'll always have his eye on the forest;

- бүрене аягы туйдыра - wolves depend on their legs for a living;

- бата башлаган корабтан качкан күселәр кебек - rats desert a sinking ship;

- тәгәрмәч эчендаге тиен кебек - like a squirrel in a cage;

- дунцгызлар алдында энже чәчү - cast one's pearls before swine;

- эт өрер, бүре йөрер - the dog barks, but the caravan goes on;

- бүредән куркып урманга бармый тормыйлар - he that's afraid of wolves should keep out of the woods.

- атны урлаткач, абзарны бикламиләр - to lock the stable door after horse has been stolen.

For many peoples, including the Tatars, personal behavior is closely related to one's religious beliefs: атны Аллага тапшыр, дилбегәне үзең тот/atny Allaga tapshyr, dilbegene uzen tot - God helps those who help themselves.

The irresponsible behavior and criminal actions are discussed in both cultures.

The lexical unit "Dog" has a positive connotation in the following phraseological units: barking dogs seldom bite; to die dog for somebody. There are no phraseological units with a positive connotation in the Tatar language. Phraseological units with the zoonym "dog" in its negative connotation are rather frequent: эт симерсә иясен mальй/et simerse ijasen talyij; to keep a dog and bark oneself; to lead/give someone a dog's life; the scalded dog is afraid of cold water; dogs that put up many hares kill none; to run with the hare and hunt with the hounds; to like something as much as a dog likes (getting) of a beating.

Some phraseological units of the "actions, behavior" thematic group are formed according to the semantic model (frame): "to influence someone by any process": төлке мае сөртү/tolke тае sortu; эт симерсә иясен тальй/et simerse ijasen talyij; дуңцызлар алдында энжсе чәчү/dungyzlar aldynda enge chachu; ак эт бәласе кара эткә/ ak et balase kara etka; to lead/give someone a dog's life.

For Tatars communication is semantically represented by "aт"/“at" (horse): ат кешндшеп, адәм сөйләшеп 
maныша/at keshnashep, adam soilashep tanysha (horses "get acquainted" during a neighing and people - in communication).

Lack of zoonym use in English and their presence in Tatar are noted during the description of interpersonal relations: ат юлда, кеше юлдашльктан сынала/at yulda, a keshe yuldashlykta; ; үгез сау да сөт бир/ugez sau da yes sot bir; бер үгездән ике тире тунамыйлар/ber ugezdan ike tire tunamyilar; ала каргадан аласың булсын/ala kargadan alasyn bulsyn; кызыл әтәч жсибәрү/kyzyl atach zhibaru; үлгән сыер сөтле була, калган сыер бетле була/ulgan syer sotle bula, kalgan syer betle; сукыр чебен/sukyr cheben.

It is interesting that the expression "love me, love my dog" conceals the following historic fact. This fixed phrase is attributed to the founder of Cistercian Order Saint Bernard Klervossky who said that "As usual the dog is being treated here as the most insignificant of all human possessions". It is necessary to be tolerant of others shortcomings and if you want to please the owner, nurse a lap-dog (Skitina, 2007).

A curious fact is that a struggle for mutual destruction, a fight to the death is personified in English by "cat": the expression Kilkenny cats apparently goes back to the legend of the fierce fight between the cities of Kilkenny and Irishtown in the $17^{\text {th }}$ century which led to their destruction. In the Tatar language elan/eлан (snake) personifies the enemy: kara elan/кара елан. Tatars used to speak in the following way about a person who does not appreciate being treated well: ishak tushak kaderen belmas/uшәк түшәк кадерен белмәс (literally: a donkey can't appreciate a featherbed). It is possible to allocate the following phraseological unit based on the degree of semantic identity in English: set a pig at a table and it will put its trotters on it.

\section{Discussions}

The interest of linguistics to studying phraseological units has not reduced. Moreover, there has been much research of the problems of their ethnic and cultural originality, which is caused by the increased aspiration to observing the questions of language interrelation and culture.

The basic provisions of cognitive linguistics are presented in works of Russian and foreign linguists such as N. D. Arutyunova (1999), A. Vezhbitskaya (2001), D.O. Dobrovolskij (1990), Yu.N. Karaulov (1976), E.S. Kubryakova (1994). Phraseologists do not avoid cognitive linguistics either. The cognitive aspects of the ethnic specifics of phraseological units are considered in works of such researchers as R.R. Zamaletdinov (2004), R.Kh. Karimova (2004), L.V. Kovalyova (2004), Z.M. Safina (2004), N.A. Skitina (2007) etc.

As is known, this article considers the lexical-semantic aspect of the concept "actions, behavior".

It should be noted, that the linguistic and culture study analysis of phraseological units with the component-zoonym in the Tatar language compared to the phraseological units of the English language allowing to identify the specific features of the national-cultural component content in the phraseological units in these languages has not yet been the object of a separate study.

\section{Conclusion}

Simple identifying of different characteristics of the language system cannot be considered currently the aim of the linguistic analysis. Anthropocentric paradigm is the key one in modern linguistics. Cultural linguistic studies and cognitive linguistics provide a new look at the phraseological material and expose it more thorough analysis in the light of new linguistic trends.

There is a uniform cognitive system of concepts in the Tatar and English languages. They are both universal elements of the cognitive base, and have a specific idiomatic-ethnical content, which manifests that creative thinking of Tatars and the Englishmen is characterized by their national identity, which has been reflected in the phraseological systems.

The material confirms that Tatar and English languages differ in variability of images expressing the analyzed concept. Thus, upon comparing the obtained concepts of the behavior and actions description, we can come to a conclusion about their similarities and differences.

\section{Recommendations}

The practical importance of the work results consists that they can be used in theoretical and practical courses of general linguistics, on practice and theory of translation, lexicology, comparative linguistics, linguocultural studies, cognitive linguistics, and in special courses on phraseology. Information on "language pictures of the world" of various linguocultural communities can be applied in the methods and practice of teaching above-mentioned languages. The concrete linguistic material can be used in lexicographic practice. 


\section{Acknowledgments}

The work is performed according to the Russian Government Program of Competitive Growth of Kazan Federal University.

\section{References}

Arutyunova, N. D. (1999). Jazyk I mir cheloveka. Moskva, 896.

Dobrovolskij, D. O. (1990). Sopostavitelnaja frazeologija: (na materiale germanskih jazykov): kurs leksii. Vladimir, 79.

Galimova, O. V. (2004). Etnokulturnaya spetsifika zoonomicheskoi leksiki, harakterizuyuschei cheloveka: na materiale russkogo $i$ nemetskogo jazykov. Kandidatskaya dissertatsija. Bashkirskij gosudarstvennyj universitet. Ufa.

Gimadeeva, A. A. (2011). Frazeologicheskie edinitsy s komponentom-zoonim v tatarskom I angliiskom jazykah $i$ ih leksikografirovanie. Kandidatskaya dissertatsija. IJALI im. G.Ibragimova AN RT. Kazan.

Gimadeeva, A. A. (2013). Natsionalno-kulturnaja spetsifika konsepta «Postupki, povedenie» (na materiale tatarskih i angliiskih frazeologicheskih edinits s komponentom-zoonim). Polikulturnoe obrazovatelnoe prostranstvo Povolzhja: puti I formy integratsii. Materialy Mezhdunarodnoy nauchno-prakticheskoi konferentsii (pp. 174-178). Kazan.

Hornby, A. S. (1995). Oxford Advanced Learner's Dictionary. Oxford University Press, 1428.

Humboldt, V. F. (1984). O sravnitelnom izuchenii jazykov primenitelno $\mathrm{k}$ razlichnymepoham ih razvitija. Izbrannye trudy po jazykoznaniyu. Moskva, 324.

Isenbet, N. (1989). Tatar telenen frazeologik suzlege. I tom. Kazan, 495.

Isenbet, N. (1990). Tatar telenen frazeologik suzlege. II tom. Kazan, 365.

Karaulov, Yu.N. (1976). Общая и русская идеография. Москва, 246.

Karimova, R. Kh. (2004). Konsept«trud/len» v parameologii nerodstvennyh jazykov: na primere nemetskogo, angliiskogo, russkogo, bashkirskogo $i$ tatarskogo jazylov. Kandidatskaya dissertatsija. Bashkirskij gosudarstvennyj universitet. Ufa.

Kovalyuova, L. V. (2004). Frazeologizatsija kak kognitivnyj protsess. Voronezh, 184.

Kubrjakova, E. S. (1994). Nachalnye etapy stanovlenija kognitizma: lingvistika - psihologija- kognitivnaja nauka. Voprosy jazykoznanija, 4, 34-46.

Longman Dictionary of Contemporary English. (2009). Harlow: Pearson Education Limited.

Safina, Z. M. (2004). Kognitivno-leksikograficheskoe opisanie frazeologicheskih edinits so strukturno-semanticheskom komponentom sveta (na materiale angliiskogo, bashkirskogo i russkogo jazykov). Kandidatskaya dissertatsija. Bashkirskij gosudarstvennyj universitet. Ufa.

Skitina, N. A. (2007). Lingvokognitivnyi analiz frazeologicheskih edinits $s$ zoonimnym komponentom (na materiale russkogo, angliiskogo $i$ nemetskogo jazykov). Kandidatskaya dissertatsija. Moskovskij gosudarstvennyj oblastnoj universitet. Moskva. Rossija.

Tatar telenen anlatmaly suzlege. (2005). Kazan: «Matbugat jorty», 848.

Tatar telenen anlatmaly suzlege. T.1. (A-J). (1977). Kazan: Tat. kit. neshr., 476.

Tatar telenen anlatmaly suzlege. T.2. (K-C). (1979). Kazan: Tat. kit. neshr., 726.

Tatar telenen anlatmaly suzlege. T.3. (T-h). (1981). Kazan: Tat. kit. neshr., 832.

Telija, V. N. (1996). Russkaja frazeologija. Semanticheskii, pragmaticheskii i lingvokulturologicheskij aspekty. Moskva, 218.

Vezhbitskaja, A. (2001). Ponimanie kultur cherez posredstvo klyuchevyh slov. Moskva, 287.

Zamaletdinov, R. R. (2004). Tatarskaja kultura v jazykovom otrazhenii. Kazan, 239.

Zykova, I. V. (2003). Sposyby konstruirovanija gendera a angliiskoi frazeologii. Moskva, 10.

Kunin, A. V. (2005). Kurs frazeologii sovremennogo angliiskogo jazyka. Moskva, 488.

Kunin, A. V. (2006). Anglo-russkii frazeologicheskij slovar. Moskva, 571.

Maslova, V. A. (2004). Lingvokulturologija. Moskva, 9. 


\section{Copyrights}

Copyright for this article is retained by the author(s), with first publication rights granted to the journal.

This is an open-access article distributed under the terms and conditions of the Creative Commons Attribution license (http://creativecommons.org/licenses/by/3.0/). 